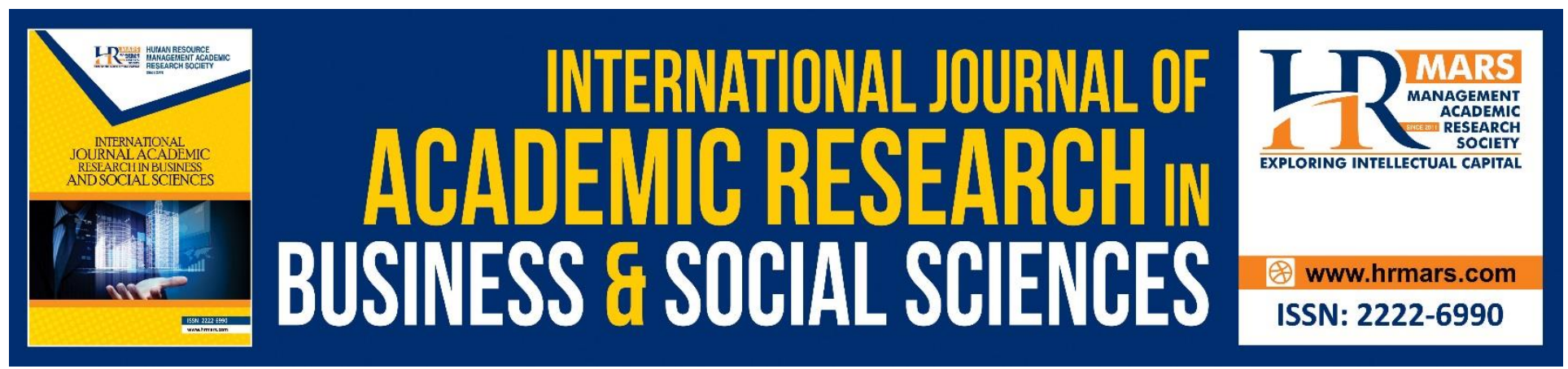

\title{
Shopping's Behaviour of Visitors at the Cross-Border Informal Market of Serikin, Sarawak
}

Siti Noradiah Amar, Fariastuti Djafar, Mohammad Affendy Arip, Mohd Khairul Hisyam Hassan

To Link this Article: http://dx.doi.org/10.6007/IJARBSS/v10-i7/7449

DOI:10.6007/IJARBSS/v10-i7/7449

Received: 04 April 2020, Revised: 05 May 2020, Accepted: 20 June 2020

Published Online: 23 July 2020

In-Text Citation: (Amar et al., 2020)

To Cite this Article: Amar, S. N., Djafar, F., Arip, M. A., \& Hassan, M. K. H. (2020). Shopping's Behaviour of Visitors at the Cross-border Informal Market of Serikin, Sarawak. International Journal of Academic Research in Business and Social Sciences, 10(7), 474-486.

Copyright: @ 2020 The Author(s)

Published by Human Resource Management Academic Research Society (www.hrmars.com)

This article is published under the Creative Commons Attribution (CC BY 4.0) license. Anyone may reproduce, distribute, translate and create derivative works of this article (for both commercial and non-commercial purposes), subject to full attribution to the original publication and authors. The full terms of this license may be seen

at: http://creativecommons.org/licences/by/4.0/legalcode

Vol. 10, No. 7, 2020, Pg. 474 - 486

http://hrmars.com/index.php/pages/detail/IJARBSS

JOURNAL HOMEPAGE

Full Terms \& Conditions of access and use can be found at http://hrmars.com/index.php/pages/detail/publication-ethics 


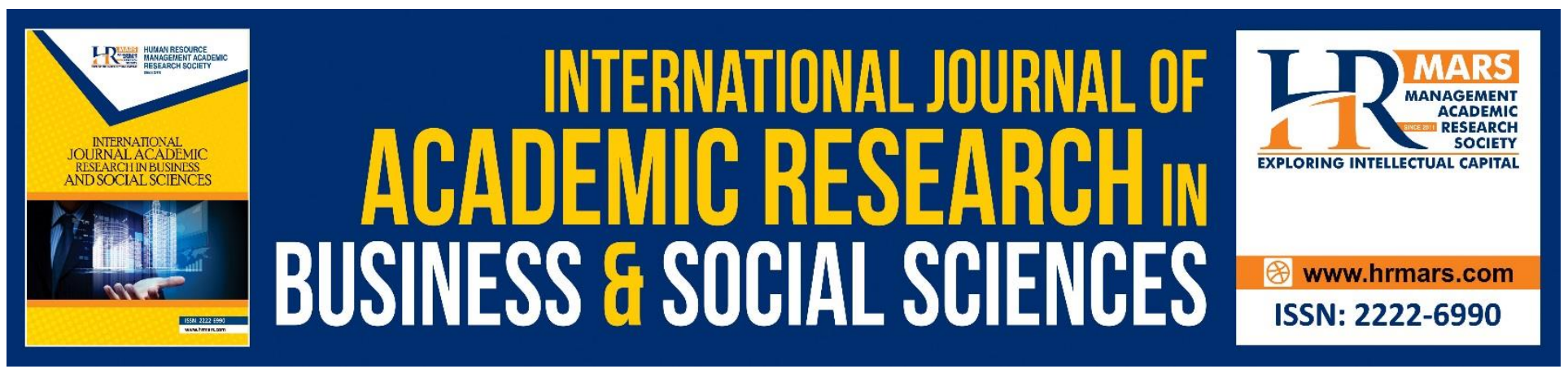

\title{
Shopping's Behaviour of Visitors at the Cross-border Informal Market of Serikin, Sarawak
}

\author{
Siti Noradiah Amar \\ Kolej Yayasan Pelajaran Johor, Malaysia
}

Fariastuti Djafar

Faculty of Economics and Business, Universitas Tanjungpura, Indonesia

\section{Mohammad Affendy Arip, Mohd Khairul Hisyam Hassan}

Faculty of Economics and Business, Universiti Malaysia Sarawak, Malaysia

\begin{abstract}
Cross-border activity especially in border towns is becoming increasingly important. There have been few studies of cross-border shopping and yet most of them have focused on macroeconomic effects rather on discovering the motivation, behavior and personal characteristics of cross-border shoppers who purchased abroad. This study aims to look the purchasing pattern of visitors at the cross-border informal market of Serikin, Sarawak according to the shopping's behavior of the visitors. By using descriptive analysis, this study found that, the main purpose visitors come to Serikin once per month with friends by using their own cars and spend less than 4 hours is for shopping. On average, they spend less than RM 499 on other cost (transportation, foods \& beverages and others) and there are only five items frequently buy by the visitors at Serikin that are clothes, vegetables, foods, electrical tools, and handicrafts. It is obvious that visitors come to Serikin for shopping. Although visitors come to Serikin with large quantity of money for shopping, but their expenditure will determine by their income.
\end{abstract}

Keywords: Purchasing Pattern, Shopping's Behavior, Sarawak.

\section{Introduction}

Malaysia is a country which borders many other countries. North of Peninsular Malaysia borders Thailand, while in the south it borders Singapore and East Malaysia borders Brunei Darussalam and Indonesia. In addition, Malaysia also has at least two informal cross-border markets along the border with Thailand (Perlis, Kelantan), one at the border of Brunei (Sarawak), and one at the border of Indonesia (Sarawak). This study is conducted at Pasar Serikin which is located at Bau, Sarawak, border between Malaysia (Serikin) and Indonesia (West Kalimantan) and is categorized as an informal crossborder market because no formal cross-border routes or Custom, Immigration and Quarantine (CIQ) exist in Serikin. During past several years, similar studies conducted by Awang et al., (2013) only 
showed the dominance of traders and commodities moving from Kalimantan, Indonesia to Serikin, Sarawak, apart from the impact of economic and socio-cultural factors on Indonesian traders who carry out the business activities at the Malaysia-Indonesia borders. However, that study did not show the impact on the visitor's side. This study attempts to fill the gap by studying purchasing pattern of visitors with some macroeconomic impacts to the local economy. The general objective of this study is to identify the purchasing pattern of visitors at the cross-border informal market of serikin, Sarawak. Specifically, this study attempts to identify the shopping's behavior of the visitors at the cross-border informal market of Serikin, Sarawak. Conducting this research will be a significant contribution to the planners and authorities involved in the development of areas in Serikin can use to create awareness and feedback from the ground level to help the government in developing strategic plans to encourage visitor spending. It is also hoped that the information provided by the researcher can planners insight to increase the volume of visitors who come enhance the crossborder shopping tourism in Serikin. In addition, this study is also crucial to government authorities so that the development of trading in Pasar Serikin can be monitored and implemented more efficiently which may help the government reverse the area's losses. This paper consists of five sections. Section 2 presents the literature review on theoretical and empirical studies. Section 3 discusses the data and methodology that is used in the empirical analysis. Section 4 presents a discussion of the results followed by the conclusion in Section 5 .

\section{Literature Review}

To understand the behavior of cross-border shoppers, it is important to know the products that crossborder shoppers buy, how often they travel, how much they spend per trip, where they usually spend their money, (Kuncharin \& Mohamed, 2013) trip purpose (Timothy, 1995; Lee, 2002; Oh et al., 2003; Lehto et al., 2004), trip accompany (Mok \& Lam, 1997; Miller, 1998; Ng, 2003; Bai \& O'Leary, 2004; Jang, March \& Woodside, 2005) and transportation mode (Ibrahim \& McGoldrick, 2003). According to Mogab et al., (2005), 92 percent of respondents in Mexico came to the United States by automobile and planned to spend more than USD500 on their shopping trip. Similarly, Ju (2010) conducted a survey on Hong Kong residents who have made at least one cross-border trip to Shenzhen. The results showed that more than 50 percent of the respondents spent 300-500 HK dollars per trip, and 30 percent of the respondents spent 100-300 HK. By looking the total number of the trips, it showed that the Hong Kong residents spent a lot of money on low-end goods. Most of the Hong Kong crossborder shoppers are one-day shopper. The data also showed that 80 percent Hong Kong residents visit Shenzhen more than once in a month. Furthermore, as Yeung and Yee, 2012 examined crossborder shopping from mainland China to Hong Kong. The study found that in the past year, on average, the majority of respondents (74.7 percent) crossed the border from mainland China to Hong Kong to shop, for less than one tripper two month period.

Trip purpose to tourist shopping behavior has been explored (Timothy, 1995; Lee, 2002; Oh et al., 2003; Lehto et al., 2004). These researchers indicate that trip purpose is closely associated with behavior and shopping expenditures. Lehto et al., (2004) found that leisure traveler spent significantly more on shopping than other groups, followed by visiting friends and relatives, and business travelers. Lee (2002) indicates that vacation travelers spent more on shopping than other purpose travelers and more attracted to products that are not available at home. This is in line with study conducted by Oh et al., (2003) which found that vacation purpose groups and visiting friends and relatives' groups were more likely to participate in shopping than business travelers during trips. 
INTERNATIONAL JOURNAL OF ACADEMIC RESEARCH IN BUSINESS AND SOCIAL SCIENCES Vol. 10, No. 7, July, 2020, E-ISSN: 2222-6990 @ 2020 HRMARS

Trip accompany is another factor in understanding tourist's consumption and expenditure patterns (Mok \& Lam, 1997; Miller 1998; Ng, 2003; Bai \& O'Leary, 2004; Jang, March \& Woodside, 2005). Shopping companion is an element that has a considerable impact on people's shopping behavior (Uzzell, 1995; Jones, 1999; $\mathrm{Ng}, 2003$ ). There is evidence that groups stay longer and consume more foods and beverages than lone customers. Groups spend more time per visit and buy larger loads at retail markets because the atmosphere can facilitate or hinder social interactions among people ( $\mathrm{Ng}$, 2003).

There are indicators that transport choices are important factors that influence visitor's shopping (Ibrahim \& McGoldrick, 2003). They found that transportation mode is significantly affects shopper's choices of shopping venues. This is contra with study conducted by Wagner, (2004) which found that the mode of transportation available for shoppers and its subsequent impact on their shopping, however, has been neglected in previous retail studies. The Office of Travel \& Tourism Industries (2004) found that international tourists to the U.S tend to utilize more transportation options offered at a destination such as cab, taxi and limousine services. It also may seem obvious when researcher indicated that the mode of transportation influence shopping because it limits traveler's ability to carry products around and back home. Air travelers may have limited ability to carry items back home due to the size, fragility and manageability of products (Pysarchik, 1989). According to Wang (2004) to understand the nature of cross-border consumption, it is important to know the products that cross-border consumers buy. As Papadopoulos (1980) stated, cross-border shoppers tend to purchase products having higher visibility, higher status, and specialty products. Furthermore, the study elaborated that cross-border shoppers have bought sporting goods, furniture, appliances, and jewelry when shopping aboard.

A study by Timothy (2005) found that the more distant the shoppers live from the border, the less frequent will they cross the border to shop. Therefore, the value of the merchandise they buy would probably be higher. In his study, separated shopping zone into three zones. The residents of the proximal shopping zone generally cross the border frequently and are willing to go shopping everyday. Thus, they may buy small ticket itemssuch as gasoline, groceries, beer, tobacco products, and restaurant meals. Residents who live in the medial shopping zone cross the border less often and tend to buy higher-value goods. Finally, residents who live farthest from the borders, very distant from the shopping zone, they seldom cross the border for shopping. However, when they do, they tend to buy big-ticket items like clothes, appliances, and electronicproducts. In Asia, as Hui and Wan (2008) found that the most popular of all items purchased are food and beverages, followed by groceries and fashion products, supporting earlier findings by Piron (2002) who said most Singaporeans went abroad and spent on clothes, handbags, shoes, cosmetics (Piron, 2002), food and grocery products (Tansuhaj et al., 1989). However, Ju (2010) studied Hong Kongers who shopped cross-border in Shenzhen. Most Hong Kongers like to buy ordinary stuffs for living such as food, clothing, housing facilities, medical and healthy services, and so on. In conformity with a previous study by Wang (2004) he cited that the most popular outshopped items were foodstuff, followed by massaging, clothes, handbags, and leather products.

In the Americas, Goh et al., (2007) and Sullivan (2008) found that Mexican nationals have shopped men's apparels, women's apparels, gifts,children's apparels, children's accessories, perfumes,cosmetics, and souvenirs in the United States. Similarly, Dimatteo and Di Matteo (1996) also investigated cross-border shopping by Canadians in the United States and found that the popular shopping items were food and drinks, petrol, groceries, beer, tobacco products, restaurant meals, 
INTERNATIONAL JOURNAL OF ACADEMIC RESEARCH IN BUSINESS AND SOCIAL SCIENCES Vol. 10, No. 7, July, 2020, E-ISSN: 2222-6990 @ 2020 HRMARS

clothes, appliances, and electronics. In Europe, Germans have shopped household products in Poland such as dairy products, food stuff, pornography in Denmark (Tomori, 2010) and cigarettes in (Chaterjee, 1991). Austrian residents outshopped medicine, medical care, dental treatment, surgery, beauty care, hairdressers, custom tailors, car repairs, travel agents, alcohol products, food stuff, cleaning and hygienic products, tobacco, and groceries in Germany (Sullivan, 2008).

\section{Methodology and Data}

As shown in Figure 1, the subject of interest in this study is purchasing pattern of visitors at the crossborder informal market of Serikin, Sarawak. The main purpose to identify the purchasing pattern of the visitor is to encourage visitors to shop at Serikin and increase the volume of the purchasing at the informal cross-border market of Serikin, Sarawak which in turns can increase the revenue. Shopping's behavior will identify visitor's trip purpose to Serikin, transportation used, frequency of shopping, partner accompany, shopping duration, average spending, types of cost for a visit to Serikin and total expenses based on the purchases made on the goods.
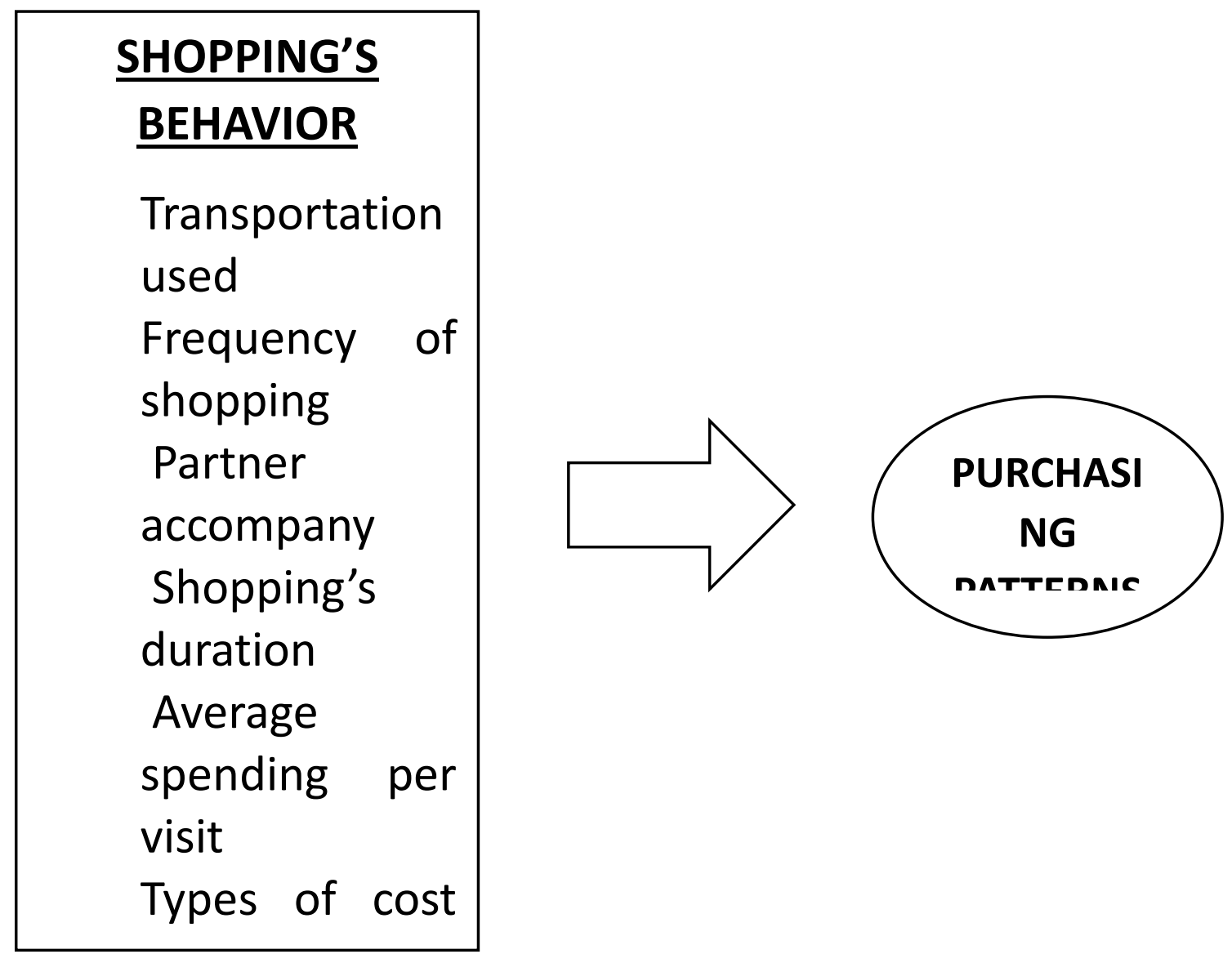

Figure 1: Conceptual Framework

The population of interests consists of visitors at the informal cross-border market of Serikin, Sarawak. Unfortunately, the Immigration Department of Sarawak did not have data on visitor's arrival into rural area such as Serikin. Therefore, in this study, in order to determine the sample size, we followed rules of thumbs provided by Sekaran (2003) and Roscoe (1975) which stated that sample 
INTERNATIONAL JOURNAL OF ACADEMIC RESEARCH IN BUSINESS AND SOCIAL SCIENCES Vol. 10, No. 7, July, 2020, E-ISSN: 2222-6990 @ 2020 HRMARS

sizes larger than 30 and less than 500 are appropriate for most research. Additionally, according to Najib (1998), 30 persons of respondent are sufficient to represent the population. According to this rule, a sample of 300 respondents, surveyed in Serikin, was randomly selected. Self-administered questionnaires were distributed randomly at Serikin in October, 2014 during weekends.

Data were collected by using questionnaires. The questionnaire is a well-established tool for acquiring information on participant's social characteristics, present and past behavior, standards of behavior or attitudes and their beliefs, and reasons for action with respect to the topic under investigation, within social science research (Bulmer, 2004). Prior to the survey, a pilot test was conducted with 20 respondents who were randomly selected at Serikin. Most of the respondents could understand and answer the questions. Thus, only few minor changes were made to the questionnaire for clarity. The pilot test was performed in order to ensure that the questions were clear and easily understood by the respondents. Generally, it was observed that the selected respondents had no major difficulties in filling out the questionnaires. The 20 survey was initially conducted at Serikin, on first weekend of October, 2014 to identify the weakness of the questionnaires. The data is analyzed by using Statistical Package for Social Science (SPSS) version 21.0. According to Najib (2003), the reliability of the questionnaire should be proved by using statistical test. The reliability for this study with Cronbach's Alpha is 0.882 . Therefore, the reliability of the questionnaire is high and strong.

The data collected from the questionnaires are analyzed using the Statistical Package for the Social Science (SPSS) Version 21.0 software. Based on the nature and the objectives of this study, descriptive analysis is used to analyze all the data. Descriptive analysis is a mathematical computation to summarize the important characteristics of the data sample (Heiman, 1996). Descriptive analysis for this research is percentage. Percentage is used to identify the shopping's behavior of the visitors at the cross-border informal market of Serikin, Sarawak.

\section{Empirical Results}

\section{Demographics' Characteristics}

Table 1 shows the demographic characteristics of the visitors at the cross-border informal market of Serikin, Sarawak. The demographic characteristic profile the respondents with respect to gender, age, marital status, residents, races, religions, level of education, occupation, individual income and household income. There are some distinct demographic characteristics of the visitors at the crossborder informal market of Serikin, Sarawak. Most of them relatively male and young, as they fall under the age group 15 to 24 years old and they are also single. Approximately 32 percent of the visitors come from Kuching and 62 percent are Malay with 72 percent of the visitors are Islam.

Table 1: Demographics' Characteristics

\begin{tabular}{ll}
\hline Items & Percentage \\
\hline Gender & \\
Male & 51.3 \\
Female & 48.7 \\
\hline Age & \\
$15-24$ & 40.7 \\
$25-34$ & 37.7 \\
$35-44$ & 9.7 \\
$45-54$ & 9.0
\end{tabular}


INTERNATIONAL JOURNAL OF ACADEMIC RESEARCH IN BUSINESS AND SOCIAL SCIENCES Vol. 10, No. 7, July, 2020, E-ISSN: 2222-6990 @ 2020 HRMARS

\begin{tabular}{|c|c|}
\hline Items & Percentage \\
\hline $55-$ above & 3.0 \\
\hline \multicolumn{2}{|l|}{ Marital Status } \\
\hline Single & 53.3 \\
\hline Married & 42.7 \\
\hline Others & 4.0 \\
\hline \multicolumn{2}{|l|}{ Residents } \\
\hline Kuching & 32.3 \\
\hline Kota Samarahan & 31.7 \\
\hline Bau & 10.3 \\
\hline Others & 25.7 \\
\hline \multicolumn{2}{|l|}{ Races } \\
\hline Malay & 62.3 \\
\hline Chinese & 6.7 \\
\hline Dayak & 15.3 \\
\hline Others & 15.7 \\
\hline \multicolumn{2}{|l|}{ Religions } \\
\hline Islam & 71.7 \\
\hline Christian / Catholic & 25.0 \\
\hline Buddhism / Hindu & 1.7 \\
\hline Others & 1.7 \\
\hline \multicolumn{2}{|l|}{ Level of Education } \\
\hline Not end school & 2.7 \\
\hline Not end standard school & 1.7 \\
\hline Standard school & 6.3 \\
\hline Secondary schools & 47.0 \\
\hline Diploma/Degree/Master/PHD & 42.3 \\
\hline \multicolumn{2}{|l|}{ Occupation } \\
\hline Unemployment & 32.3 \\
\hline Government & 31.0 \\
\hline Private & 15.0 \\
\hline Self-employed & 15.0 \\
\hline Working with others & 6.7 \\
\hline \multicolumn{2}{|l|}{ Individual income } \\
\hline$<1500$ & 53.5 \\
\hline$>1500$ & 46.5 \\
\hline \multicolumn{2}{|l|}{ Household income } \\
\hline$<2000$ & 58.6 \\
\hline$>2000$ & 41.4 \\
\hline
\end{tabular}

With respects to background information concerning the level of education, there is no clear evidence exists suggesting that visitors are generally more-educated. This is further attested to by the fact that most of the visitors are unemployment (32.3 percent) and from the lowest incomes 
INTERNATIONAL JOURNAL OF ACADEMIC RESEARCH IN BUSINESS AND SOCIAL SCIENCES

Vol. 10, No. 7, July, 2020, E-ISSN: 2222-6990 @ 2020 HRMARS

group, receiving average individual income per month of less than RM 1500 (53.3 percent) and with average household income per month of less than RM 2000 (58.6 percent).

\section{Visitor's Behaviour}

Table 2 profiles the respondents with respect to trip purpose, transportation, frequency of shopping, partner accompany, shopping duration, average spending, cost incurred by the visitors for a visit to Serikin and total expenses based on the purchases made on the goods. The main purpose visitors come to the cross-border informal market of Serikin, Sarawak is for shopping (74.3 percent). Those visitors come to Serikin with friends (44.3 percent) once per month ( 27.0 percent) by using their own cars (71.3 percent) and spend approximately 0 to 4 hours ( 87.3 percent) at Serikin.

Table 2: Visitor's Behavior

\begin{tabular}{ll}
\hline Items & Percentage \\
\hline Trip purpose & 74.3 \\
Shopping & 25.7 \\
Tourism & \\
\hline Personal transportation & 22.0 \\
Motorcycles & 71.3 \\
Cars & \\
\hline Public transportation & 12.7 \\
Van & 15.3 \\
Bus & 21.0 \\
Rental car & \\
\hline Frequency of shopping & 9.7 \\
Once per week & 10.3 \\
Once per two weeks & 27.0 \\
Once per month & 22.7 \\
Once per six months & 22.3 \\
Once per year & 8.0 \\
Others & \\
\hline Partner accompany & 7.7 \\
Alone & 44.3 \\
Friends & 41.3 \\
Family & 1.7 \\
Alone \& Friends & 0.7 \\
Alone \& Family & 4.3 \\
Friends \& Family & \\
\hline Shopping duration (Hours) & 87.3 \\
$0-4$ & 12.3 \\
5 - 9 & 0.3 \\
10 - above & 10.7 \\
\hline Average spending per visit in Serikin (RM) & \\
$0-499$ & \\
$500-999$ & \\
& \\
\hline
\end{tabular}


INTERNATIONAL JOURNAL OF ACADEMIC RESEARCH IN BUSINESS AND SOCIAL SCIENCES Vol. 10, No. 7, July, 2020, E-ISSN: 2222-6990 @ 2020 HRMARS

\begin{tabular}{|c|c|}
\hline Items & Percentage \\
\hline $1000-1999$ & 2.0 \\
\hline 2000 - above & 0.3 \\
\hline \multicolumn{2}{|l|}{ Other Cost: } \\
\hline \multicolumn{2}{|c|}{ Transportation costs (RM) } \\
\hline$<500$ & 99.6 \\
\hline$>500$ & 0.4 \\
\hline \multicolumn{2}{|c|}{ Foods and beverages (RM) } \\
\hline$<100$ & 99.6 \\
\hline$>100$ & 0.4 \\
\hline \multicolumn{2}{|l|}{ Others (RM) } \\
\hline$<150$ & 90.4 \\
\hline \multirow[t]{2}{*}{$>150$} & 9.6 \\
\hline & de on the Goods \\
\hline \multicolumn{2}{|l|}{ Clothes } \\
\hline$<$ RM 500 & 98.8 \\
\hline > RM 500 & 1.2 \\
\hline \multicolumn{2}{|l|}{ Vegetables } \\
\hline$<$ RM 50 & 96.9 \\
\hline$>$ RM 50 & 3.1 \\
\hline \multicolumn{2}{|l|}{ Foods } \\
\hline$<$ RM 100 & 95.0 \\
\hline$>$ RM 100 & 5.0 \\
\hline \multicolumn{2}{|c|}{ Electrical Tools } \\
\hline$<$ RM 350 & 96.7 \\
\hline > RM 350 & 3.3 \\
\hline \multicolumn{2}{|l|}{ Handicrafts } \\
\hline$<$ RM 500 & 97.2 \\
\hline$>$ RM 500 & 2.8 \\
\hline
\end{tabular}

With respects to spending per visit in Serikin, on average, most of the visitors (87.0 percent) are found to spend less than RM 499 for a visit. This is further attested by visitors spent on other cost (transportation (99.6 percent), foods \& beverages (99.6 percent), and others (90.4 percent)) which are less than RM500, RM 100 and RM 150 respectively. On the other hand, it is also further attested that there are only five items frequently bought by the visitors at the informal cross-border market of Serikin, Sarawak that are clothes, vegetables, foods, electrical tools, and handicrafts. About 98.8 percent and 97.2 percent of visitors spent less than RM 500 for clothes and handicrafts, 96.9 percent spent less than RM 50 for vegetables, 95.0 percent spent less than RM 100 for foods (sea foods, fried crisp, honey) and 96.7 percent spent less than RM 350 for electrical tools. 
INTERNATIONAL JOURNAL OF ACADEMIC RESEARCH IN BUSINESS AND SOCIAL SCIENCES Vol. 10, No. 7, July, 2020, E-ISSN: 2222-6990 @ 2020 HRMARS

\section{Qualitative Results Based on In-Depth Interview with Key Informants}

From the economical point of view, in the border regions, cross-border informal market of Serikin, Sarawak can have an important impact over the local commerce. Cross-border shopping has drawn growing interest from many scholars as it has significant impact on revenues on both sides of the border (Yeung \& Yee, 2012). Moreover, research regarding cross-border shopping has been carried out in different regions, for example like America, Asia, Europe and other border regions. Most of the study would include income leakages from rural to metropolitan areas and would focus on the pattern of cross-border shopping and its impact on the economy of the host destination (Anaman \& Ismail, 2002; Bygvra, 1999; Chaterjee, 1991; Di Matteo \& Di Matteo, 1996; Piron, 2002; Subramaniam, Devadason \& Sundararaja, 2008; Sullivan \& Kang, 1997; Timothy \& Butler, 1995; Tomori, 2020; Wang, 2004). The impacts of cross-border informal market of Serikin, Sarawak on local economy can be seen from positive and negative impacts. Concerning positive impacts, it was clear that cross-border informal market in Serikin had generated income to the residents. The interviews showed that, the peak time, according to the most residents, were school holidays and public holidays especially hari raya aidilfitri and Gawai. During the holiday, the car park is full, thus, residents provide their housing sites as the car park for the visitors. Thus, this generates income to the residents as they will charge each of the vehicles that parking at their housing sites.

Concerning economic linkages and employment, it was clear that cross-border informal market had generated significant employment creation in Serikin. In the initial phase this was started by a few traders from Indonesians that offered vegetables likes chilies, long beans, sweet potatoes, okra, and many more to the villagers. It was followed by others Indonesians that offered Batik Indonesia and other products made in Indonesia. As Serikin boomed as shopping places, it generated employment initially within the kampong when the villagers also offered their goods, and then drew in outside traders from other local resident. Concerning negative impacts, the interview with the Senior Custom Officer, Jeritish Ak Goneck, reported that illegal activity for example smuggling is widely occurs at the border of Serikin (Malaysia) - Kalimantan (Indonesia). By using unofficial routes, it will cause the volume of smuggling increase, thus increase the price of the goods. As a result, this smuggling activity would cause economic leakage which by spending of visitors decrease due to the increase in prices of the goods. Informal cross-border market of Serikin, Sarawak has not been properly recorded thus they are not covered by the national account. Thus, the national account may subject to under-valued due to unrecorded trade. Moreover, some imported goods may not be a duty-free goods which may cause revenue lost for the Malaysian government. Some export goods may also be subsidized goods in which foreigners are not entitled to enjoy the subsidy benefit. For example, there is RM 9,544,538 of sugars and RM 413,280 of carbonate beverages were exported to Kalimantan, Indonesia in 2014 without any official route (Immigration Department of Serikin, 2014).

\section{Conclusions and Recommendations}

In terms of demographic characteristics, most of the purchasing is made by single young male, which come from Kuching. These visitors are Malay and Islam and from the lowest incomes group. As discussed above, this finding is supporting and contradicts with previous studies. These supporting and differentiating results may point toward a need to expand our present understanding of purchasing pattern at the informal cross-border market. The main purpose visitors come to Serikin once per month with friends by using their own cars and spend less than 4 hours is for shopping. On average, they spend less than RM 499 on other cost (transportation, foods \& beverages and others) 
and there are only five items frequently buy by the visitors at Serikin that are clothes, vegetables, foods, electrical tools, and handicrafts.

It is obvious that visitors come to Serikin for shopping. Nevertheless, they were only spent small amount of money to shop. As for this study, most of the visitors are from low income group which is less than RM 1, 500 (individual income) and less than RM 2, 000 for household income. Therefore, this finding is in line with the Keynes income and expenditure theory which is according to Keynes, it is the total money income which determines the total expenditure of the community. It is changes in income rather than in the money supply which cause changes in the aggregate demand. When income increases, aggregate demand for goods and services also increases. Visitors spend more and the price level rises. On the contrary, with the decline income, the aggregate demand fails. Thus, visitors spend less and price level falls. Although visitors come to Serikin with large quantity of money for shopping, but their expenditure will determine by their income. In a nutshell, by understanding the purchasing pattern of the visitors in terms of the shopping's behavior, it can facilitate traders to provide goods with respects to the visitor's taste, needs and desire which in turns can increase the expenditure of visitors at the informal cross-border market of Serikin, Sarawak, thus increase the revenue.

\section{Corresponding Author}

Mohd Khairul Hisyam Hassan

Faculty of Economics and Business, Universiti Malaysia Sarawak (UNIMAS)

Email: hmkhisyam@unimas.my

\section{Acknowledgement}

The authors wish to thank Universiti Malaysia Sarawak (UNIMAS) for supporting the dissemination of this research. This research was supported by the Ministry of Education, Malaysia, through the Fundamental Research Grant Scheme, FRGS/SS07(01)/978/2013(19).

\section{References}

Anaman, K. A., \& Ismail, R. A. (2002). Cross-border tourism from Brunei Darussalam to Eastern Malaysia: an empirical analysis. The Singapore Economic Review, 47(1), 65-87.

Awang, A. H., Sulehan, J., Bakar, N. R. A., Abdullah, M. Y., \& Liu, O. P. (2013). Informal cross-border trade Sarawak (Malaysia) - Kalimantan (Indonesia): A catalyst for border community's development. Asian Social Science, 9(4), 167.

Bygvra, S. (2009). Distance and Cross-border shopping for alcohol. The Journal of Economic Perspectives, 26(2), 141-163.

Chatterjee, A. (1991). Cross-border Shopping: Searching for Solution. Canadian Business Review, 18(4), 26-28.

Di Matteo, L., \& Di Matteo, R. (1996): An analysis of Canadian cross-border travel. Annals of Tourism Research, 23(1), 103-122.

Ibrahim, H. F., \& McGoldrick, P. J. (2003). Shopping choices with public transport options. Burlington, VT: Ashgate Publishing Company.

Jang, S. S., Bai, B., Hong, G. S., \& O'Leary, J. T. (2004). Understanding travel expenditure patterns: A study of Japanese pleasure travelers to the United States by income level. Tourism Management, 25(3), 331-341. 
INTERNATIONAL JOURNAL OF ACADEMIC RESEARCH IN BUSINESS AND SOCIAL SCIENCES

Vol. 10, No. 7, July, 2020, E-ISSN: 2222-6990 @ 2020 HRMARS

Jones, M. A. (1999). Entertaining shopping experiences: An exploratory investigation. Journal of Retailing and Consumer Services, 6(3), 129-139.

Ju, P. (2011). Research on the characteristics of spatial behavior of Hong Kong cross-border Consumer. International Journal of Retail \& Distribution Management, 18(4), 8.

Kuncharin, W., \& Mohamed, B. (2013). Cross-border shopping motivation, behaviors and ethnocentrism of Malaysian in Hatyai, Thailand. International Journal of Social, Education, Economic and Management Engineering, 7(4), 1017-1027.

Lee, H. C. (2002). Determinants of visitor expenditure on a local festival: A tobit analysis. Tourism Research, 26(1), 31-46.

Lehto, X. Y., Cai, L. A., O'Leary, J. T., \& Huan, T. C. (2004). Tourist shopping preferences and expenditure behaviors: the case of taiwanese outbound market. Journal of Vacation Marketing, 10(4), 320-332.

Miller, D. (1998). A Theory of Shopping. Itaca, NY: Cornell University Press.

Mok, C., \& Lam, T. (1997). A model of tourists' shopping propensity. A case of Taiwanese visitors to Hong Kong. Pacific Tourism Review, 1(2), 137-145.

Abdul Ghafar, M. N. (1998). Penyelidikan Pendidikan, Johor Bahru: Universiti Teknologi Malaysia.

$\mathrm{Ng}, \mathrm{C}$. F. (2003). Satisfying shoppers' psychological needs: From public market to cyber-mall. Journal of Environmental Psychological, 23(4), 439-455.

Oh, Y. (2007). An exploration of tourist shopping (Doctoral dissertation, Texas A\&M University).

Papadopoulos, N. G. (1980). Consumer outshopping research: review and extension. Journal of Retailing, 56(4), 41-58.

Piron, F. (2002). International out shopping and ethnocentrism. European Journal of Marketing 36(1/2), 189-210.

Pysarchik, D. T. (1989). 'Tourism Retailing'. In Tourism Marketing and Management Handbook edited by Witt, S. and L. Moutinho. London, Prentice Hall: 553-556.

Sekaran, U. (2003). Research methods for business: A Skill Building Approach (4 ${ }^{\text {th }}$ ed.). New York: John Wiley \& Sons Inc.

Subramaniam, T., Devadason, E., \& Sundaraja, S. (2008). Cross-Border shopping behavior of Bruneians in Limbang, Sarawak: A preliminary analysis. Fakulti Ekonomi \& Pentadbiran University of Malaya.

Sullivan, P. M., \& Kang, J. (1997). Information Sources and motivational attributes of Canadian crossborder shoppers: Apilot study. International Journal of Commerce \& Management,7(1), 88-107.

Tansuhaj, P., Ong, W. C., \& McCullough, J. (1989). International outshoppers: What are they like? Singapore Marketing Review, 4, 93-7.

Timothy, D. J., \& Butler, R. W. (1995). Cross-border shopping: A north American perspective. Annals of Tourism Research, 22(1), 16-34.

Tomori, M. (2010). Investigating shopping tourism along the Borders of Hungary - a Theoretical perspective. GeoJournal of Tourism and Geosites, 6(2), 202-210.

Uzzell, D. L. (1995). The Myth of the indoor city. Journal of Environmental Psychology, 15, 299-310.

Wagner, B. (2004). Shopping choices with transportation options. Tourism Management, 25, 811814.

Wang, D. (2004). Hong Kongers' cross-border consumption and shopping in Shenzen: Patterns and motivations. Journal of Retailing and Consumer Services, 11(3), 149-159. 
INTERNATIONAL JOURNAL OF ACADEMIC RESEARCH IN BUSINESS AND SOCIAL SCIENCES

Vol. 10, No. 7, July, 2020, E-ISSN: 2222-6990 @ 2020 HRMARS

Yeung, R., \& Yee. (2012). A profile of the Mainland Chinese cross-border shoppers: Cluster and discriminant analysis. Tourism Management Perspectives 4, 106-112. 